\title{
CHANGES IN ARGUMENT STRUCTURE IN THE COURSE OF DERIVATION IN HUNGARIAN*
}

\author{
GÁBOR ALBERTI \\ Department of Linguistics \\ University of Pécs \\ Ifjúság útja 6. \\ H-7624 Pécs \\ Hungary \\ albi@btk.pte.hu
}

\begin{abstract}
For all types of derivation characterised as productive by Kiefer (2000), the original version of Model Tau (Alberti 1997), dealing only with verbal derivation coming with no category change, can be extended to the entire spectrum of derivations; moreover, it can be extended in a straightforward way: the single novel factor is the central case frame peculiar to particular word categories. For instance, if the predicator is a noun, what corresponds to the case frame $\langle$ Nom, Acc $\rangle$ in the sphere of verbs, is the case frame $\langle$ Nom, Poss $\rangle$; this mapping is immediately observable in the case of $-O ́ j A$ (Laczkó 2000b), a suffix forming nouns in an argument-structure retaining way (elcsábit 'seduce' $\rightarrow$ elcsábitója '(someone's) seducer'). The case frame characteristic of the output word category supplies an upper limit, within which the actual realization can belong to five types that precisely coincide with the five basic types of category-preserving verbal (and participial) derivation discussed in Alberti ( $i b i d$.). How can these five basic types be derived? The crucial factor of each argumentstructure transition is "advancement" of an argument (parallel with the "degradation" of another argument) in a sense that can be precisely defined in Model Tau.
\end{abstract}

Keywords: word formation, thematic theories, argument hierarchy, Model Tau

In the nineties I worked out a universal theory on potential case-frame manifestations of verbal argument structures and systematizing their

* Writing this paper has been sponsored by OTKA (No. T38386). Special thanks are due to the following colleagues for their valuable comments on earlier versions of this paper: Katalin É. Kiss, Emese Bérces, Magdolna Ohnmacht.

1216-8076/\$20.00 @ 2006 Akadémiai Kiadó, Budapest 
transitions by the name Model Tau, chiefly illustrated by Hungarian data and analyses (see e.g., Alberti 1988b,a, 1992-1993, 1994, 1997, 1998b), in which the holistic manner of Zsilka's thinking and his observations I judge to be the most valuable and opportune (e.g., Zsilka 1966, 1982) have been reconciled with the decisive elements of thematic theories (e.g., Komlósy 1992); ${ }^{1}$ joining the trend according to which - instead of attempting to fix a particular list of thematic roles - morphosyntactically relevant lexical-semantic information is to be captured by means of more abstract argument hierarchies (e.g., Bresnan-Kanerva 1989; Grimshaw 1990; Dowty 1991).

This version of Model Tau, thus, contains statements - primarily constraints - on verbal derivations coming with no category change, sorting them out into five types of transition. This project aims at extending the system to all kinds of derivation claimed by the authors of the volume on (Hungarian) morphology of the Strukturális magyar nyelvtan series (Kiefer 2000) to be (at least semi-) productive. What is primarily claimed is that in this "extended Model Tau", into which cases of wordformation with non-verbal output or input have been integrated, a single novel factor should be allowed for in the course of describing argument structure changes - while retaining the hypothesis on the five sorts of transition types; nothing else but what is straightforward and inevitable: the case-frame possibilities characteristic of the category of output words.

Let us consider the content of the paper. After sketching and illustrating Model Tau (in section 1), I expound the crucial principles that the system of Hungarian argument structure transitions shown in the Appendix relies on (section 2), then distinct sections will be devoted to reviewing derivations retaining, expanding or reducing argument structure (sections $\mathbf{3}-\mathbf{5}$ ).

\section{Absolute chain of influence-relative case frames}

One of the crucial ideas that Model Tau relies on is that a given argument frame of a given verb form is to be characterized on the basis of a family of related argument structure versions to be assembled in a specific way, instead of the often uncertain methods based on lists of thematic roles.

${ }^{1}$ I would like to recall the prosperous and far-reaching family of thematic theories by mentioning the following seminal works: Gruber (1965); Fillmore (1968); Jackendoff (1987); Rappaport-Levin (1988); Parsons (1995); Williams (1995).

Acta Linguistica Hungarica 53, 2006 
There are, for instance, at least five participants in the conceptual frame of the verb form elásat 'make sy dig sg into the ground', shown in (1d) below: in addition to the explicitly appearing privateer giving orders and the treasures getting in the depths of the ground, in certain argument structure versions (ASV) of ás 'dig' further participants can also be mentioned, such as the pirates carrying over the work of digging in fact, the pieces of soil moved (and, hence, directly affected) by them, and the holes accommodating the treasures. With regard to traditions, I have attempted to associate these roles with thematic-role labels, but in this way a potential characterization is such that the privateer, enforcing his will on others, and the pirates, who are carrying out some job, should both be qualified as Agents, and the pieces of soil, which are moving, the holes appearing, and the treasure, placed in the ground, are all regarded as Patients. As separation is a preferred aim, the privateer can be characterized as a Causer, and the holes can be understood as the Goal of a change of state pertaining to the ground of an area. I do not enter into details, I have only intended to point to the above mentioned uncertain nature of selecting thematic roles. What has been proposed in Model Tau as a relevant lexical-semantic characterization, is a polarized chain of influence, demonstrated in (1e) below; whose innovation lies in the fact that a given role in a given ASV belonging to a given verb is essentially to be calculated on the basis of a linearly ordered list of related ASVs (illustrated in (1a-d) below)). What can be said about this linear ordering here is that an appropriate list should consist of ASVs with richer and richer meaning content; the construction of such lists requires precise and quite intricate procedures as well as the algorithmic construction of polarized chains of influence does (their presentation would go beyond the scope of this paper, but see Alberti 1997).

(1) (a) A kalózok (a szigeten) ásták a földet. 〈Agent, Patient〉 the pirate-pl (the island-sup) dig-past-3pl the soil-acc 'The pirates were digging the ground (on the island).'

(b) A kalózok gödröket ástak. the pirate-pl hole-pl-acc dig-past-3pl

$\langle$ Agent, Goal $\rangle$ 'The pirates were digging holes.' (c) A kalózok elásták a rabolt kincseket.
the pirate-pl away-dig-past-3pl the stolen treasure-pl-acc
'The pirates buried the stolen treasures.'

$\langle$ Agent, Patient 2 〉 
(d) A kalózvezér elásatta a rabolt kincseket. 〈Causer, Patient〉 the privateer away-dig-cause-past-3pl the stolen treasure-pl-acc 'The privateer had the stolen treasures buried.'

(e) The chain of influence belonging to elásat with strong/weak Agent-like and Patient-like roles (on the basis of $(1 \mathrm{a}-\mathrm{d})$ ): Causer $\rightarrow$ Agent $\rightarrow$ Patient $\rightarrow$ Goal $\rightarrow$ Patient $_{2}$

The initial step of the algorithm mentioned above is to mark the ASV illustrated in (1a) above as the primitive core of the chain of influence to be constructed; the argument occupying the subject/object position in this ASV is qualified as a weak agent/weak patient in our approach, respectively, indicated by thin arrow-like underline above in (1e). ASV (1b) provides a new argument in its object position: this will be the first strong patient (thick arrow-like underline). The new object in ASV (1c) is to be qualified as the successive strong patient in the chain of influence. ASV (1d) provides a new argument in its subject slot. In a situation like this the left edge of the chain of influence is to be enriched - with a strong agent.

The two fundamental (falsifiable) universal predictions of Model Tau exert restrictions on the subject and the object of certain transitive members of ASV families - as "relative" ASV selections: the chain of influence in the background and the qualification of certain arguments as strong agents or patients are to be "respected", i.e., the absolute polarized chain of influence is to be complied with. An object, thus, is not allowed to precede the subject serving as its co-argument in the same ASV according to the chain of influence in the background; further, a strong patient will not appear as the subject of a transitive member of the ASV family, and a strong agent will not serve as an object. These two fundamental constraints say nothing about arguments with a weak polarity (weak agents/weak patients); that is, Model Tau offers no categorical statements concerning arguments belonging to a primitive core (in the sense defined above). The reason lies in the observation that arguments in the primitive core show major (less predictable) variability in respect of realization as subjects or objects. ${ }^{2}$

${ }^{2}$ In the family partly demonstrated in (1), thus, there is no ASV (subcategorized by an arbitrarily affixed variant of the verb stem ás 'dig') in which, for instance, the argument that the role of holes is associated with would appear as the subject with the privateer's argument as the corresponding object (2a). Passive ASVs, 
(2) Constraints on relative transitive ASVs belonging to an absolute chain of influence:

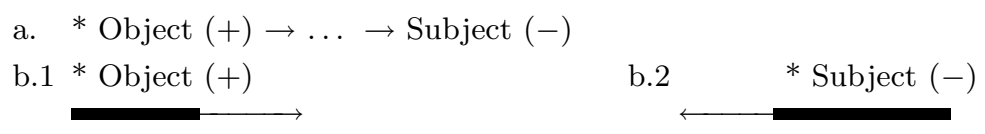

In the background of the falsifiable synchronic statements there is a psycholinguistic hypothesis to be verified statistically, which is completed with a typological conjecture, a hypothesis on language acquisition and another one on the evolution of human language, providing a coherent model.

According to the first hypothesis, an absolute chain of influence belonging to a particular verb stem is a true reflection of the flow of influence "in reality," at least in the following sense: the chain of influence in the grammar will coincide with the real flow of influence if this latter flow can be clearly appraised (e.g., in the realm of physical powers) while, otherwise, the chain of influence should be regarded as the outcome of a predominantly accidental process of grammaticalization. The minimal pair please/like can serve as an excellent illustration of the latter case (e.g., Peter likes Mary versus Mary pleases Peter): like has been grammaticalized in a way that the thematic frame 〈Experiencer, Stimulus〉 is mapped onto a case frame $\langle$ Nom, Acc $\rangle$, whereas this assignment is in the reverse order in the case of please, yielding a case frame $\langle$ Acc, Nom〉, despite the fact that it is not easy to indicate any difference to be considered relevant between the two meanings. In the relation between an Experiencer and a Stimulus there is no (inevitable) real physical impact. An Experiencer, on the one hand, can be taken as a participant whose feelings manifest themselves in the form of activities, but the role of a Stimulus can also be regarded in a way that triggering feelings is a result of different activities. In the case of digging, however, the flow of impact is essentially clear: digging people move pieces of soil, and not the other

unobjectionable in lots of languages, are not to be regarded as a violation of the prediction in question, as they are intransitive variants with the agentive argument in an oblique case (e.g., 'Holes were dug by the pirates.'). There is no transitive ASV, either, in which the holes would be selected to occupy a subject position with the argument of treasures as the corresponding object (2b.2). As for the possibility of a variant illustrated by the sentence ${ }^{? ?} A$ kalózvezér már órák óta ásatja az embereit 'The privateer has been making his people dig for hours.' (cf. (2b.1)), nothing is claimed about it, as the role of the people digging is only weakly agentive; which is in perfect harmony with the uncertain judgment concerning the grammaticality of the sentence just mentioned ("??"). 
way round; and holes are the result of the dislocation of these pieces of soil, so holes are "later" both in a logical and in a chronological sense. As for the relation between holes and treasures, this relation may be taken as an artificial impact, grammaticalized according to our human aspect. As for the side of causers, the privateer's influence is abstract, of course, but it is deeply rooted in the "secondary reality" of human group hierarchies.

The above mentioned hypothesis in the area of language typology says that there are two central argument functions in every natural language: a negative relative role $(-)$ of agentive polarity, and a patient-like positive relative role $(+)$. In our approach a transitive ASV is defined as their simultaneous occurrence, which is hypothesized to serve the purpose of revealing a fragment of the polarized chain of influence in the background. The constraint formulated in (2a), hence, can straightforwardly be understood as a consequence of this requirement demanding compatible representation. An intransitive ASV is regarded as such in which the same participant plays both the causer's negative relative role and the causee's positive relative role $(-/+)$. What is highlighted in the case of a sentence like The pirates have been digging for hours, is the pirates' getting tired rather than the fact that pieces of soil have been moved or, probably, holes have been created. In the accusative type of languages (which English and Hungarian belong to), the negative central function and the positive central function are to be indicated by the unmarked Nominative and the morphologically (and/or syntactically) marked Accusative case, respectively, whilst the single argument of intransitive ASVs is in the Nominative case. This latter statement also holds true of the ergative type of languages, but in this type it is the positive central function that will remain case-morphologically unmarked (Absolutive case), whereas the negative central function will get an Ergative case. By introducing these two sorts of central polarity (Alberti 1997), not only these two language types can be covered but the entire rich realm of intermediate/mixed types reviewed by Komlósy (1982).

The hypothesis on language acquisition mentioned in an earlier paragraph predicts a straightforward connection between the absolute polarized chain of influence (in the background) and the relative ASV realizations ("on the surface"): an infant who is acquiring a language - parallel with learning what kinds of physical and psychic influences work in the world around him/her - will construct the polarized chains of influence corresponding to verbs on the basis of ASVs heard, and then (s)he will (be able to) construct new ASVs never heard by him/her. In the knowl- 
edge of the data in (1) and the general constraints in (2), for instance, an infant is able to construct an ASV like the one shown in (3a) below, which is perfect indeed. Nevertheless, we should be careful about these positive predictions; it is better to speak about tendencies, which may be more or less reliable partly depending on different language-specific factors. This precaution concerns the possibility of intransitive ASVs as well (e.g., ?? Mostanában az a fönök heppje, hogy napokon át ásat 'Nowadays the boss is hipped on making [people] dig for days.').

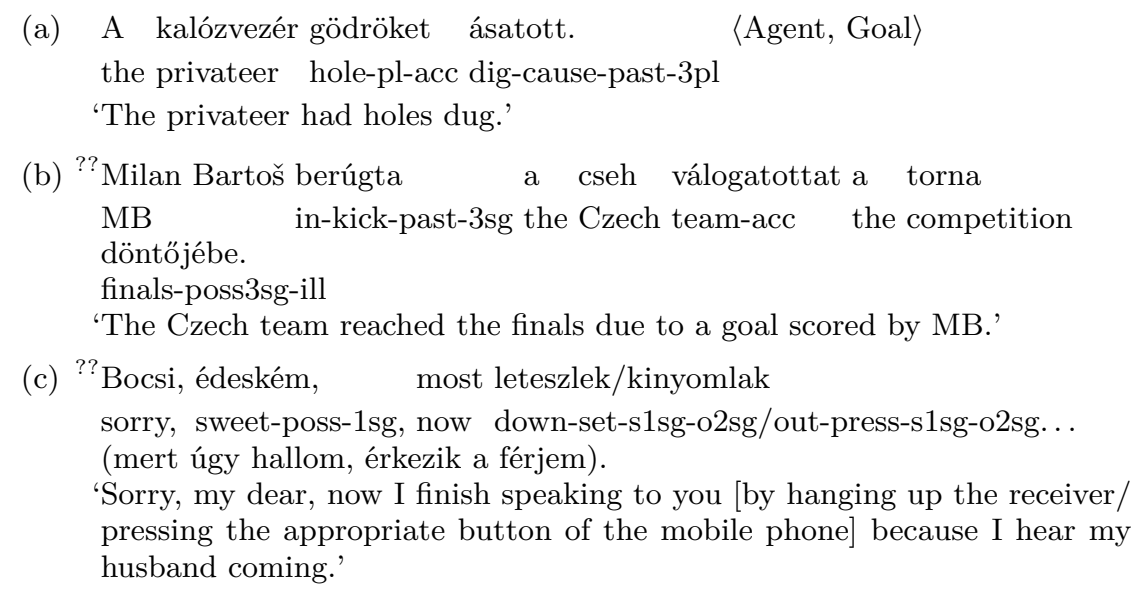

The hypothesis on language evolution, also mentioned above, is a similar basic element of the philosophy that Model Tau relies on: it is assumed to be an important part of human adjustment to the current world that we strive for expressing connections which are "far away" in the physical reality but relevant to us by means of a single verb (and argument structure), by connecting "distant" roles in this way. The privateer in (1d), for instance, does not touch the soil; it is even possible that he does not touch the treasures either. We can say, nevertheless, that the digging activity in the situation demonstrated in (1d) serves his purpose of putting the treasures in holes. The diachronic process can be detected in synchrony in the form of funny bloomers or unguarded wordings, like those in (3b-c) above. The famous Czech forward, for instance, kicked a ball, immediately, and in this way he could 'kick a goal'; which is of a crucial relevance in the course of a single match as well as in the course of a series of matches, whose finals can be reached for the whole Czech national team by means of such instances of scoring goals. Bartoš, hence, managed to exert a relevant impact on his team by kicking, immediately, a 
ball. It is, then, a problem which can be modeled by stochastic processes from this point (Alberti 1988b,a) whether a new ASV will be naturalized in the language of a social layer or in a technical jargon, and then in the standard language, or this potential process will abort at birth. Similar thoughts can be formulated in connection with the example in $(3 \mathrm{c})$; what is the crucial point here is that the lady telephoning exerts some relevant influence on her interlocutor by finishing their conversation through immediately exerting influence on an object.

In what follows, methods of Model Tau are illustrated by two other ASV families, in (4) and (5) below. It is worth noticing that the same four thematic roles are mapped onto different case frames; we can conclude, hence, that traditional thematic representations cannot optimally capture the semantic character relevant from morphosyntactic points of view. The crucial difference lies in allowing for what has been called the primitive ASV, a proposal peculiar to Model Tau in this form.

$$
\begin{aligned}
& \text { (a) Betört egy ablak. } \\
& \text { break-past-3sg a window }
\end{aligned}
$$

'A window broke.'

(b) Ez a kalapács még egy vastag ablakot is betörne. 〈Instr., Patient〉 this the hammer even a thich window-acc even break-cond-3sg 'This hammer could break even a thick window.'

(c) Péter betörte az ablakot (egy kalapáccsal). 〈Agent, Patient, (Instr.)〉 Peter break-past-3sg the window-acc (a hammer-inst) 'Peter broke the window (with a hammer).'

(d) Mari betörette az ablakot Péterrel / egy kalapáccsal.

$\langle$ Causer, Patient $(\mathrm{Ag} / \mathrm{In})\rangle$ Mary break-cause-past-3sg the window-acc Peter-inst / a hammer-inst 'Mary made Peter break the window.'/'Mary had the window broken with a hammer.'

(e) The polarized chain of influence belonging to betöret (on the basis of $(4 a-d)$ ):

Causer $\rightarrow$ Agent $\rightarrow$ Instr $\rightarrow$ Patient

The intransitive ASV in (4a) above will serve as the primitive core of the ASV family on the basis of which the chain of influence belonging to the ASV in (4d) can be calculated. The Instrument (or Natural Force) which appears in variant (4b), thus, provides a new subject, to be identified 
as a strong agent (according to the algorithm of calculation mentioned above). The Agent and the Causer in variants (4c-d) above provide further strong agents, resulting in the polarized chain of influence shown in (4e). In the ASV family demonstrated in (5) below, however, the primitive ASV in (5a) is transitive and, hence, the argument belonging to the prickly object is to be qualified as a weak agent. As a result of the constraint in (2b.1) above, thus, it is predicted that the entire ASV family whose members are mentioned in (4) will not contain an ASV that would correspond to the one shown in (5b) (cca. * Péter odatörte a kalapácsot az ablakhoz [Peter towards-break-past-3sg the hammer-acc the window-all], intended meaning: 'Peter knocked the hammer against the window, and the hammer broke.').

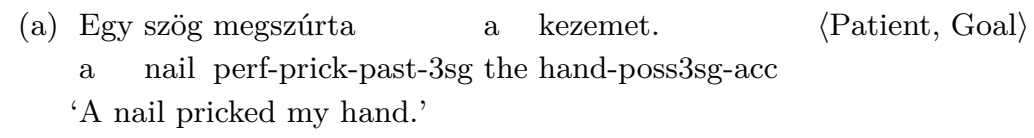

(a) Egy szög megszúrta

a kezemet.

$\langle$ Patient, Goal $\rangle$

a nail perf-prick-past-3sg the hand-poss3sg-acc

'A nail pricked my hand.'

(b) Péter beleszúrt egy szöget az abroncsba.〈Agent, Patient, Goal〉 Peter into-prick-past-3sg a nail-acc the tyre-ill

'Peter pushed a nail into the tyre.'

(c) Péter kiszúrta az abroncsot egy szöggel. 〈Agent, Pat/Ins, Goal/Pat〉 Peter out-prick-past-3sg the tyre-acc a nail-inst

'Peter punctured the tyre with a nail.'

(d) Mari kiszúratta

az abroncsot.

$\langle$ Causer, Goal/Pat〉

Mary out-prick-cause-past-3sg the tyre-acc

'Mary had tyre punctured.'

(e) The polarized chain of influence belonging to kiszúrat

(on the basis of $(5 \mathrm{a}-\mathrm{d})$ ):

Causer $\rightarrow$ Agent $\rightarrow$ Instrument $\rightarrow$ Patient

At this point it is worth raising the dividing dilemma of thematic theories (e.g., Dowty 1991, section 5): whether the identifiable arguments of related ASVs can be associated with distinct thematic roles. Can it be said, for instance, that the prickly thing in ASV (5a) is a Natural Force, as it functions according to its natural character (like the wind blows), whereas in ASV (5b) it appears as a Patient, as it is moved towards a goal, and in ASV (5c) it is the Instrument of an Agent's exerting (fatal) influence on an earlier Goal, which qualifies as a Patient in this version in the spirit of this approach? Followers of this approach, thus, think 
that participants to be identified play slightly modifying roles from ASV to ASV, explaining the abundant supply of ASVs that can be observed from language to language. This approach suffers from a cruel paradox, however: how can we consider the roles associated with different ASVs to be identical/identifiable? I prefer the view of the opposite party (Alberti 1997), which I judge to be traceable back to the original approach by Fillmore (1968) relying on deep cases: thematic labels of identical/ identifiable roles should be constant, which does not exclude at all that the same thematic frame could be mapped onto different case frames. The problem with this approach is that in the course of an isolated examination of particular ASVs the traditional definition-like formulations (Komlósy 1992) present a basis for associating the "identical" roles with different thematic labels, as has been discussed above.

Model Tau, due to its "dynamic" approach, can essentially avoid the dividing dilemma discussed above, because in this theory arguments are not attempted to be characterized on the basis of "what is in the real world" but what has been grammaticalized in the language. An entire ASV family supplies the absolute information in the background on grammaticalized chains of influence and poles according to agentivity (where verb stems are fixed in a family but no rigid formal restrictions on affixation are applied), whilst particular ASVs, due to their peculiar case frames, can express slight relative "shift of emphasis": which are the participants whose connection the speaker considers to indicate the impact of influence relevant in the given situation, including reflexivity exhibiting intransitive ASVs.

\section{Word formation and ASV transition coming with it: advancing and degrading arguments}

My starting points in questions concerning word formation are the observations and definitions serving as commom denominators in the "structuralist" morphology edited by Kiefer (2000) and written by many authors. ${ }^{3}$ My aim is not to rebuff or to correct their statements but to show that the original Model Tau can be extended in an optimally straightfor-

\footnotetext{
3 The descriptive / systematizing chapters of the volume Kiefer (2000) are of principal importance to the topic of the present paper: Kenesei (2000); Kiefer-Ladányi (2000a,b); Laczkó (2000b,c); Komlósy (2000).
} 
ward manner to all the cases qualified by the volume as (at least semi-) productive derivations.

The first question to face obviously concerns the nature of word formation. A sufficient criterion is change of category, whose crucial element can be recognized in the fact that the accommodating or refusing syntactic and/or morphological environments are not the same in the input phase and in the output phase of the given derivation. The type of derivation coming with no category change can be captured by modifying this criterion so that what is referred to will be the morphosyntactic environments that the word can (or cannot) accommodate, that is, practically case frames. The derivational connection between successive members of the ASVs of the families shown in (1), (4) and (5) above belongs to this latter type of word formation, as Model Tau in its original form (Alberti 1997) had been intended to account for derivational relations within the category of verbs. Word formation may come with (explicit) derivational affixation, which is an additional factor that sufficiently proves that derivation has taken place but is not necessarily to be regarded as an obligatory component of derivation: I agree (e.g., Alberti 1997) with the introduction of the concept of conversion (Kiefer-Ladányi 2000a,b; Laczkó 2000b), defined as the sort of derivation with no (explicit) morphological change of the input word form. In the least easily evaluable cases even changes in case frame should be dispensed with. In the case of the transition shown in $(1 \mathrm{a}-\mathrm{b})$, for instance, the fact of derivation can be detected by indicating that the argument structure has been changed as certain argument slots are under the influence of a modified selectional restriction (Komlósy 1992) (the role of the "dug soil" can be occupied by solid things whereas the participant corresponding to the holes is "made of air").

As shown by the series of examples in (5) above, due to the "functional" definition of derivation (enriched with elements of a logical nature) peculiar to Model Tau, what can be accepted as a morphological modification serving as a formal concomitant to derivation is not only adjoining morphemes to a relative stem but substituting an affix for another one. That is, we can regard versions of a word which cannot be related by some productive morphological rule but are due to more or less accidental diachronic processes (Alberti 1997, 149) as standing in an input-output derivational relation. What is at issue is essentially the blocking effect discussed by Komlósy (1992), according to which, an otherwise productive morpheme-adjoining operation will not function where 
both an appropriate input word form and an appropriate output word form exist, in the form of words coming from earlier states of the language (e.g., the causative version of fö 'be on the boil' is not fövet (cf. lö 'shoot' - lövet), but föz 'cook'; it is just the irregular variant föz that prevents the theoretically potential regular variant fövet from being used).

Model Tau has been intended to provide a descriptively and explanatorily adequate theory (and system) of possible transitions of central frames (Alberti 1997); thus, in the case of word formation, the question is as follows: which argument was and which argument will be in the nominative case, in the accusative case or in some oblique case. In the extended version of Model Tau, in which derivations coming with category change are also allowed for, this question may be changed as follows: what kinds of central case frames can be associated with different categories of words? Let us start, then, with reviewing this question, by casting the first glances at the chart in the Appendix, serving as the central topic of this paper.

As was established above, in the Hungarian language, which belongs to the accusative family of languages, the transitive case frame is such that the argument playing the causer's role, i.e., the one with the negative central role, will be associated with Nominative case, whereas the "causee", i.e., the argument with the positive central role, will get the Accusative; see (6) below. An intransitive case frame consists of a single Nominative, which we regard as associated with both central roles in a situation like this (6b). Participles essentially also use the central case frame $\langle\mathrm{NOM}, \mathrm{ACC}\rangle$, with the following differences: their subject-like argument typically gets no phonetic form ((6c): " bility is not excluded in a few marginal or archaic constructions (6d); and finally in a construction with an infinitive in its center the subject can appear in a possessor-like way (6e). In the systematizing chart in the Appendix, derivations with a verbal or a participial output have been placed in the same column, with regard to the essential similarity of the central case frames. The reason of this similarity can be found in the fact that participles behave as transitional categories in a way that their output nominal nature is expected by their "accommodating environtment" in sentences, whereas environments that they can potentially accommodate, i.e., their argument strucutres, show their input (verbal) nature.

(a) Mari megtelefonálta a hírt.

$\langle\mathrm{NoM}, \mathrm{ACC}\rangle=\langle-,+\rangle$

Mary perf-phone-past-3sg the news-acc

'Mary telephoned somebody about the news.'

Acta Linguistica Hungarica 53, 2006 
(b) Mari telefonálgat.

$\langle\mathrm{NOM}\rangle=\langle-/+\rangle$

Mary phone-dim-3sg

'Mary is telephoning [aimlessly].'

(c) [látva a helyzetet] / egy [sokakat piszkáló] fiú / [see-adv the situation-acc] / a [many-pl-acc annoy-presprt] boy / (Mit akarsz?) [Megtelefonálni a hírt Péternek.] $\langle\emptyset$, ACC $\rangle$ (what-acc want-2sg) [perf-phone-inf the news-acc Peter-dat] '[seeing the situation]' / 'a boy [annoying a lot of people]' / '(What do you want?) [To telephone Peter about the news.]'

(d) ? egy sokakat piszkáló, de [maga is sokak által piszkált] a many-pl-acc annoy-prespar, but [self too many-pl by annoy-pastprt] fiú / [bika rugaszkodván] / a [helyzet kínálta] lehetőség boy / [bull push-off-adv] / the [situation offer-pastprt-poss3sg] facility 'a boy who annoys many other people but is [also annoyed by many people]' '[As the bull pushed off,... ]'/'the facility [offered by the situation]'

(e) (Tudod, mi volt a legnagyobb hiba?) know-2sg what be-őast-3sg the greatest mistake $\begin{array}{lll}\text { Marinak megtelefonálnia azt a hírt. } & \langle\text { Poss, ACC }\end{array}$ Mary-dat telephone-inf-3sg that-acc the news-acc '(What was the greatest mistake?) For Mary to phone about that news.'

(7) (a) 'egy másokat részegséggel vádoló, közben [maga is] részeg / an other-pl-acc drunkenness-inst accuse-presprt, whilst self too drunken / Mari részeg. / Mari büszke a lányára. $\langle\mathrm{Nom}\rangle$

Mary drunken / Mary proud the daughter-poss3sg-sub 'one who accuses others of drunkenness whilst he himself is also drunken' / 'Mary is drunken.' / 'Mary is proud of her daughter.'

(b) egy [részeg] tengerész / [Részegen] táncoltunk.

a [drunken] sailor / [drunken-adv] dance-past-1pl

'a drunken sailor' / 'We danced in a state of drunkenness.'

(c) Ez sértés / a törvények durva megsértése! this violation / the law-pl crude violation-poss3sg 'This is an offence / a crude violation of laws.'

(d) Nem türöm a sértéseket / a törvények durva megsértését. $\langle\emptyset$, Poss $\rangle$ not bar-1sg the offence-pl-acc / the law-pl crude violation-poss3sg-acc 'I will not have the offences / the crude violation of laws.'

The examples in (7) above are intended to illustrate the central case frame of ASVs associated with nominal predicators. It is excluded that 
an argument belonging to a nominal predicator would be marked with Accusative. A predicator of the category adjective, also depending on its function, has a single central case, which is Nominative (7a); moreover, this argument position is typically associated with no phonetic form (7b). The latter situation is characteristic of the case frame of an adverbial predicator (7b), that is why the adjectival and adverbial derivational morphemes share a column in the Appendix. As for a predicator of the category noun, it will turn out that it is worth attributing to it a central frame in which the nominative case marking is associated with the negative central role (7c), or does not appear explicitly $(7 \mathrm{~d})$, whereas the marker of the positive central role is the possessor function $(7 \mathrm{c}-\mathrm{d})$. I give here the following observation as the first argument in favor of this approach: as a result of nominalization, the object of the input verb turns into a possessor: megsérti a törvényt $\rightarrow$ a törvény(-nek a) megsértése [perf-violate-3sg the law-acc $\rightarrow$ the law(-dat the) perf-violatenoun-poss3sg] 'violate the law' $\rightarrow$ 'violation of the law' (Alberti 1995).

As for the output case frame of a derivation, the case frame characteristic of the output word category only supplies an upper limitation, within which the actual realization can still belong to five types; and I claim that these five possibilities precisely coincide with the five basic types of category-preserving verbal (and participial) derivation discussed in the original 1997 framework of Model Tau (Alberti 1997). How can these magical five basic types be derived? The crucial factor of each ASV transition is claimed to be nothing else but the advancement of an argument, that is, the increase of its relative role. As will be gone over in (8) below (see the transition schemes listed in the left column), what can be regarded as an "advancement" in the case of a non-central argument is obtaining a central role (which is in accordance with its polarity) (8a-b), while a central participant can obtain an even higher position by acquiring both central roles $(8 \mathrm{c}-\mathrm{d})$. In the case of a transitive input, which is to be regarded as the basic case, the advancement of an argument in the above discussed sense will necessarily come with the degradation of a central input argument. It can be checked that if we declare a principle requiring the possible "least change" in the course of a transition, according to which a single ASV transition can result in some change in the central role of at most two arguments (i.e., no argument besides the argument "to be advanced", or one argument if and only if this change is inevitable because of the universal constraints demonstrated in (2) above), then the degradation should follow the transition patterns listed in the right-hand 
side column: an object gives its relative central position to a new object (8a), or a subject to a new subject (8b), or one of the two central arguments leaves the central zone resulting in an intransitive argument frame with the single argument necessarily bearing the Nominative in the accusative type of languages $(8 \mathrm{c}-\mathrm{d})$; and finally the case illustrated in $(8 \mathrm{e})$ below is the "degenerate" transition variant, in which there is simply no change in argument structure (here the fact of derivation can be indicated on the basis of changes in morphological and/or semantic factors).

(8) (a) ken némi vajat a kenyérre $\rightarrow$ megkeni a kenyeret spread some butter-acc the bread-sub $\rightarrow$ perf-spread the bread-acc vajjal $+\mathrm{N} \rightarrow+\mathrm{C} \quad+\mathrm{C} \rightarrow \mathrm{N}$ butter-inst 'spread some butter on the bread' $\rightarrow$ 'spread the bread with butter'

(b) Péter ás egy gödröt $\rightarrow$ Mari ásat egy gödröt

Peter dig a hole-acc $\rightarrow$ Mary dig-cause a hole-acc Péterrel $-\mathrm{N} \rightarrow-\mathrm{C} \quad-\mathrm{C} \rightarrow \mathrm{N}$ Peter-inst 'Peter digs a hole.' $\rightarrow$ 'Mary makes Peter dig a hole.'

(c) olvas egy regényt $\rightarrow$ olvas read a novel-acc $\rightarrow$ read 'he is reading a novel' $\rightarrow$ 'he is reading'

(d) Péter elkeni a pacát $\rightarrow$ a paca elkenődik $+\mathbf{C} \rightarrow-/+\mathbf{C}+\mathbf{C} \rightarrow \mathbf{N}$ Peter smudge the ink-blot-acc $\rightarrow$ the ink-blot smudge-middle 'Peter smudges the ink-blot' $\rightarrow$ 'the ink-blot gets smudged'

(e) Péter kavarja a levest $\rightarrow$ Péter kavargatja a levest $\emptyset$ $\emptyset$ Peter stir the soup-acc $\rightarrow$ Peter stir-dim the soup-acc 'Peter is stirring the soup' $\rightarrow$ 'Peter keeps on stirring the soup (occasionally)'

(9) (a) 1. Péter telefonál $\rightarrow$ Péter megtelefonálja a hírt $\quad+\mathbf{N} \rightarrow+\mathbf{C}$ Peter telephone $\rightarrow$ Peter perf-telephone the news-acc 'Peter is telephoning' $\rightarrow$ 'Peter phones sy about the news'

2. fakad a genny a kelésből $\rightarrow$ kifakad a kelés $\quad+\mathrm{N} \rightarrow-/+\mathrm{C}$ burst the pus the core-ela $\rightarrow$ out-burst the core 'pus bursts from the core' $\rightarrow$ 'the core bursts'

(b) 1. Péter dolgozik $\rightarrow$ Mari dolgoztatja Pétert Peter work $\rightarrow$ Mary work-cause Peter-acc 'Peter works' $\rightarrow$ 'Mary makes Peter work'
2. $\rightarrow$ Mari új varrónővel dolgoztat
Mary new needlewoman work-cause
'Mary makes a new needlewoman work [M. has a new needlewoman]' 


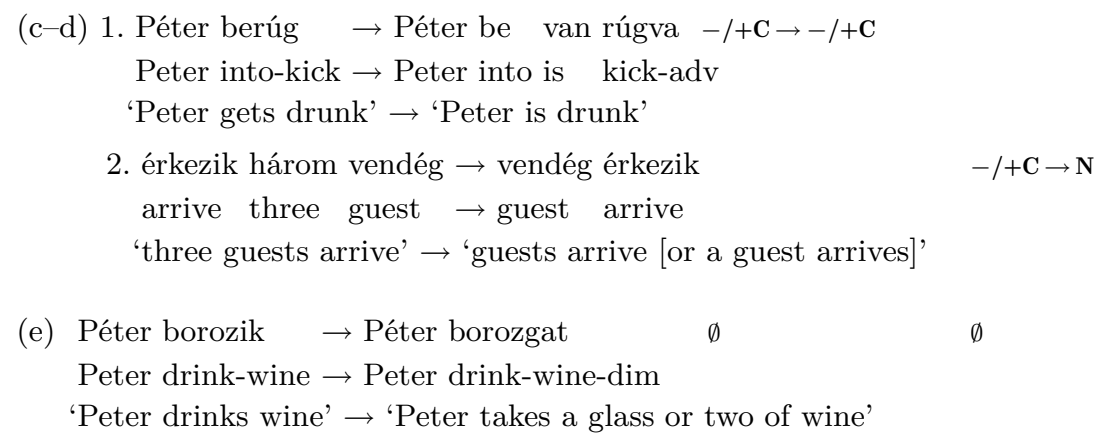

Then, in the series of examples in (9) above, the variants with an intransitive input corresponding to the five cases listed in (8) have been gone through. It can be checked that - theoretically - two "degenerate" transitions correspond to each transitive basic case; and, witnessed by the examples, what has been predicted does exist in Hungarian, indeed. In type (a), a positive central role is requested by an argument coming from a non-central status (8a), (9a). When the input is intransitive (9a), this request can be satisfied in two ways: the given argument either acquires a positive pole (and only this role, doing with the object position), or it deprives the single input central argument of both central roles. Variants of $(9 \mathrm{~b})$ show the same in a symmetrical configuration: a new argument appears and acquires the subject position, while either letting the input central argument retain its object status or entirely pushing it out from the central zone. Types (8c) and (8d) coincide in the case of an intransitive input $(9 \mathrm{c}-\mathrm{d})$, but the single central participant can have two fates: either a double central role can be attributed to it - resulting in an identical transition (which is an approach that I will argue for in section 5), or the single argument can be deleted from the central zone, entirely emptying this zone (see also section 5). Finally, (9e) shows that the "degenerate" variant of the identical transition can also take place when the input is "degenerate," too, that is, intransitive - which is no surprise.

In the following three sections, we will look through the Hungarian derivations qualified as productive or at least semi-productive by means of the chart in the Appendix with the purpose of demonstrating that the output case frame is determined in each case by the output word category and its classification according to the five basic types of transition discussed above; the degenerate types with an intransitive input can be unequivocally classified on the basis of the corresponding basic transi- 
tive types, as operations of derivation (in Hungarian) will not sort out according to the cardinality of the central zone of the input

\section{Kinds of derivation retaining argument structure}

Let us start studying the systematizing chart in the Appendix with the first one out of the five major sections, where we are not to count with advancing or degrading arguments but only formal changes in the central zone triggered by a (potential) change in word category.

Even this latter change is minimal in the left upper square, where the output case frame practically coincides with the input case frame because of retaining the essentially verbal character. The most identical transition is characteristic of the (diminutive/frequentative) derivational suffix - $g A t$, which produces no change in category at all: it converts a verb into a verb, the input subject remains a subject, and the input object also retains its object position (see (8e) above). As indicated by a symbol "\$" in the chart, the possibility of a degenerate intransitive input is not excluded either (9e). The same could be said about the mood suffix - $h A t$; but it is so productive and its meaning contribution is so compositional that nowadays it is not considered to be a derivational suffix.

Ways of participle formation retaining argument structure were illustrated in (6c-e) above. The subtypes can be characterized by different slight changes in case frame as follows: the input Nominative is substituted by a possessor-like form (6e), or a form with no phonetic realization (6c); although there are special constructions (6d) where the Nominative is retained (Nom $\rightarrow$ Nom / Poss / $\emptyset$ ). There are three sorts of adjectival participles in Hungarian, of which the present ("continuous") participle is derived by an argument-structure retaining ASV transition; furthermore, it is often mentioned (e.g., Laczkó 2000a) that the past ("perfect") participle has a growing variant typical of the "newspaper language" (e.g., \% a tegnap játszott csapat [the yesterday play-pastprt team] 'the team that played yesterday'), which also belongs to the type in which argument structure is retained (it expresses temporal antecedence in contrast to the present participle expressing simultaneity; cf. the normal past participle produces a passivization-like ASV transition, see section 5).

There are three derivations forming verbs from adjectives which can be regarded as representatives of the transition retaining argument structure. At the input practically a subject should be counted with, which will undergo no change: e.g., sötét a haja [dark the hair-poss3sg] 'his 
hair is dark' $\rightarrow$ sötétedik a haja [dark-become the hair-poss3sg] 'his hair is darkening', zöld a rét [green the field] 'the field is green' $\rightarrow$ kizöldül a rét [out-green-become the field] 'the field greens out', sárga a gólyahír [yellow the cowslip] 'cowslips are yellow' $\rightarrow$ sárgállik a gólyahír [yellow-llik the cowslip] 'cowslips gleam yellow'. It would go beyond the scope of this paper to provide semantic changes associated with formal changes in argument structure in general but here I give an illustration of semantics: in the first two examples a static statement concerning the state of an argument $x$ is substituted for a dynamic eventuality structure describing the change of $x$, whose result state (Alberti-Ohnmacht 2005) just coincides with (the cumulative phase of) the input eventuality structure; whereas in the last example the input static description is set in an intensional dimension (Alberti-Ohnmacht ibid.): 'it is the speaker's intensive impression that (the) cowslips are yellow'. Other sorts of semantic changes can be observed in cases of verb formation from nouns: e.g., ' $x$ is a bashaw' $\rightarrow$ ' $x$ behaves as if it were true that [ $x$ is a bashaw]' (basa $\rightarrow$ basáskodik), ' $x$ is a soldier' $\rightarrow$ ' $x$ behaves in an appropriate way in the state that $[x$ is a soldier]' (katona $\rightarrow$ katonáskodik). What is relevant to us here: the input intransitive case frame will undergo no formal changes.

Now let us look at the argument-structure retaining subtypes of derivation with no category change: the verbal $-g A t$, which has already been mentioned, the adjectival $-(A) s$, and the family of diminutive suffixes of nouns (e.g., $-(c s) k A$ ). It is interesting that they share a semantic element, some diminutive character, pervading the borderline of word categories: 'he does that occasionally/not so seriously'/'it is essentially such but the given property does not manifest itself in its entirety'/'it is that but smaller/less developed than the prototypical version'.

The adjectival privative suffix semantically produces an opposite property (' $\mathrm{x}$ is brave' $\rightarrow$ ' $\mathrm{x}$ is not brave'), but the case frame will not change $\left(x_{\mathrm{Nom}}\right.$ bátor/bátortalan).

As for the suffix - $A n$, I follow Kiefer and Ladányi (2000b, 4.4.1.) in considering it a derivational morpheme forming adverbs; in this approach it is obviously a transition retaining argument structure: e.g., részeg $\rightarrow$ részegen ' $x$ is drunk' $\rightarrow$ ' $x$ does something whilst [ $x$ is drunk]'.

The derivations mentioned in the chart turning nouns into adjectives (e.g., király 'king' $\rightarrow$ 'super' (in slang), gáz 'gas' $\rightarrow$ 'unpleasant' (in slang)) and adjectives into nouns (e.g., angol 'English' $\rightarrow$ 'Englishman') also retain argument structure. It should be noted in connection with the type of nouns like autószerelo" [car-repair-presprt] 'car-mechanic' (noun) that 
the immediate source of this noun is an adjectival version of autószerelö (autószerelö brigád 'team repairing cars'), to be formed by conversion, and this adjective is formed from the present participial construction autót szerelö [car-acc repair-presprt] 'one repairing cars' through a kind of derivation which will be mentioned as patient incorporation in section $\mathbf{5}$.

I follow Laczkó (2000b) in classifying - $O j A$ [presprt+poss] as a noncomposite suffix forming nouns from verbs; and in the extended version of Model Tau we can claim that it is just this derivational morpheme that realizes noun formation from verbs in an argument-structure retaining way. Remember the last section: what corresponds to the verbal central case frame $\langle\mathrm{NOM}, \mathrm{ACC}\rangle$ in the category of nouns is a central frame $\langle$ Nom, Poss $\rangle$. The examples below, thus, show instances of identical, but intercategorial, transition:
(a) Mari szereti / elcsábítja Pétert. Mary love-3sg / seduce-3sg Peter-acc 'Mary loves/seduces Peter.'

(b) Mari a szeretője / elcsábítója Péternek. Mary the love-Ója / seduce-Ója Peter-dat 'Mary is Peter's sweetheart/seducer.'

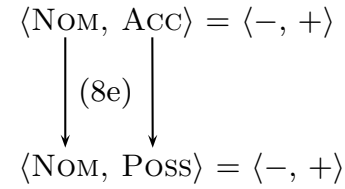

$\langle$ NOM, POss $\rangle=\langle-,+\rangle$

\section{Kinds of derivation expanding argument structure}

As was elucidated in section 1, Model Tau relies on the hypothesis (also of distinguished importance in Zsilka's $(1966,1982)$ philosophy) that languages can get accustomed to the changing world via the development of polarized chains of influence; and the creative element of this process is nothing else but the two sorts of ASV transition expanding argument structure.

First of all, let us consider the derivational morphemes mentioned in the chart which enrich the chain of influence on the side of "causees". It has been discussed in connection with (8a) above that what practically happens in the basic case of this type of transition (where the input is transitive) is that the input object is substituted by a new argument in the object function. Verbs ken 'spread' and fakaszt 'cause to burst' are representatives of two distinct basic types. In the former case the content of the transition can be characterized as follows: in the input situation an Agent moves a Patient to a Goal (e.g., 'somebody spreads some butter on a bread') while in the output situation our attention is concentrated 
on the fact that the Goal has been affected (totally) as a result of this movement ('he spreads the bread with butter'). In the latter case the input situation describes a movement in the opposite direction, that is, the Patient moves away from a Source (e.g., 'he has some pus burst from the core'), while in the output situation we concentrate our attention on the change of state pertaining to the Source, i.e., its becoming empty ('he has the core burst').

The two sorts of transition discussed in the last paragraph do not require an Agent to move the Patient: we can speak about the total affectedness of a Goal by the saturation characteristic of it (zsonganak a méhek a kertben [swarm-3pl the bee-pl the garden-ine] 'bees are swarming in the garden' $\rightarrow$ zsong a kert a méhektöl [swarm-3sg the garden the beepl-abl] 'the garden is swarming with bees'; sárgállanak a gólyahirek a réten [yellow-llik-3pl the cowslip-pl the field-sup] 'cowslips gleam yellow in the field' $\rightarrow$ sárgállik a rét a rengeteg gólyahírtól [yellow-llik-3sg the field the many cowslip-abl] 'the field is yellow with the many cowslips), and the total affectedness of a Source by the emptiness characteristic of it (fakad a genny a kelésböl [burst the pus the core-ela] 'pus bursts from the core' $\rightarrow$ kifakad a kelés [out-burst-3sg the core] 'the core bursts'). The degenerate intransitive input follows the transition pattern demonstrated in (9a.2): the argument playing the positive central role in the input ASV leaves the central zone, so the new argument entering the central zone promptly obtains a double polarity, and the resulting output is an intransitive ASV again.

In the case of an intransitive input, the other transition pattern predicted in (9a.1) is also quite frequent: in this pattern the single central argument of the input ASV gives the new argument of the central zone only its positive central feature, while retaining the negative feature. What is produced in this way is a transitive output version: e.g., telefonál 'telephone' $\rightarrow$ megtelefonálja a hírt [perf-telephone-3sg the news-acc] 'phone sy about the news'. The existence of the new argument is due to the fact that the sentences "emitted" in the course of telephoning have constituted a coherent unit that can be characterized as a piece of news; thus the Agent's permanent activity which does not necessarily aim at a purpose in the input situation is represented as a telic event in the output version: the purpose is producing a Patient like in the transition type of fon 'weave' (Hungarian shows the same transition: 'weave the silk thread into a shirt' $\rightarrow$ 'weave a shirt'). 
Transition pattern (9a.1) is a very productive source of ASVs often described as constructions with "pseudo-objects", in which the object does not belong to the verb as its argument ("szótárilag nem vonzata az igének"; e.g., Bene 2005). The activity of swimming, for instance, is basically expressed by means of an intransitive ASV (see (11a) below), but numerous transitive versions can be formed (11b-f):

(11) (a) Péter úszik.

Peter swim-3sg

'Peter is swimming.'

(b) Péter (le)úszott öt kilométert.

Peter (down-)swim-past-3sg five km-pl-acc

'Peter has swum five kilometers.'

(c) Péter átúszta

a Csatornát.

Peter across-swim-past-3sg the Channel-acc

'Peter has swum the Channel.'

(d) Péter végigúszta a délutánt.

Peter throughout-swim-past-3sg the afternoon-acc

'Peter swam all afternoon.'

(e) Péter világcsúcsot úszott.

Peter world-record-acc swim-past-3sg

'Peter swam a world record.'

(f) Péter leúszta Pált.

Peter down-swim-past-3sg Paul-acc

'Peter and Paul swam a race and Peter won.'

(g) Péter összeúszott magának egy nyaralót.

Peter together-swim-past-3sg self-dat a cottage-acc

'Peter has earned so much money by swimming professionally that he could buy a cottage.'

(h) Péter halálra úszta magát.

Peter death-sub swim-past-3sg self-acc

'Peter had swum himself to death.'

The following question arises in connection with Bene's (2005) point of view: how can we know what belongs to a verb "lexically" as its argument? The approach based on pseudo-objects is problematic because the completion of an event can be measured out by considering just the participant in question, which is characteristic of arguments, moreover, of distinguished arguments (Tenny 1994). If somebody intends to swim 
five kilometers, for instance, and he has begun to do that, then at a given moment it can be measured out according to the distance absolved up to that particular moment how matters stand, and the entire event can be considered to have been accomplished successfully (i.e., it can be said that he has reached the cumulative point (Alberti-Ohnmacht 2005) when he has absolved the fifth kilometer.

It is quite clear why "pseudo-objects" cause problems to traditional theories of thematic roles: a threatening number of ASVs can be produced with them, different sorts, as could be seen above, but fairly independently of the idiosyncratic properties of verb stems, and in all these ASVs there seems to be no better approach then labelling them as Patients, which is no favorable result for an ambitious thematic theory. In Model Tau, however, in which thematic role labels have been got rid of and more abstract argument hierarchies are relied on (see section $\mathbf{1}$ ), nothing prevents us from proposing what is suggested by the appearance of the Accusative case: they are ordinary arguments occupying the object position. We hypothesize that alternative chains of influence develop with arguments incommensurate according to the partial ordering that the sum of the family of these chains of influence constitutes, as in the case of ás 'dig' (see also (1)):

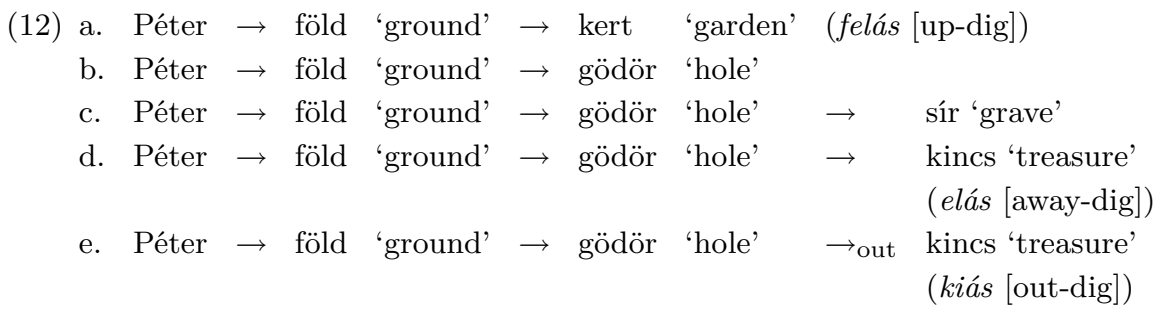

As can be seen above, it can be expressed in Hungarian by using an appropriate object (and an appropriate verbal prefix in certain cases) that a whole garden is affected by digging its soil (12a), whilst no real holes are created; in other ASVs (12b-e) a real hole is created, which can serve as a grave $(12 \mathrm{c})$ or a place to hide a treasure in it $(12 \mathrm{~d}-\mathrm{e})$; and it depends on the morpheme appearing as a prefix of the verb stem ás 'dig' whether the treasure gets in this place (12d) or out of this place (12e).

Thus the intricate system of relations between the numerous arguments "swarming" around a given verb stem can be accounted for by means of the partially ordered structure of families of branching chains of influence. As for the calculation of the meaning of a particular ASV, 
what is to be allowed for, in addition to the verbal prefix if any, is the semantic type of the object (e.g., time, distance, place, person). The interpreter's task is practically to figure out the likeliest potentially relevant relation between a person swimming and a time mentioned, or a place, or a person, or the Agent himself/herself (11b-h) (in a sufficiently richly structured lexical network, Alberti 2000). It is a secondary question whether a given meaning should be calculated from its pieces again and again on the basis of the lexical network, or registered as a new item.

Now let us turn to the mysterious suffix $-((j) A)$, which appears in the word kalap-ja-i-m [hat-poss-pl-1sg] 'my hats' in its full-fledged form but seems to be present in a null phonetic form in hajó-Ø-i-m [ship-posspl-1sg] 'my ships'. We follow Szabolcsi (1992) and her predecessors in considering this morpheme to indicate the state of being possessed. I would like to add, however, the uncustomary hypothesis that this suffix should be regarded as belonging to the derivational elements considering its property of increasing the number of arguments: e.g., $x$ kalap ' $x$ is claimed to be a hat' $\rightarrow x$ Péter kalapja ' $x$ is claimed to be Peter's hat', i.e., a hat and Peter are claimed to stand in a certain relation $\left(\mathrm{cf.}{ }^{*} x\right.$ Péter kalap). As a derivational morpheme, it should be placed in the cell of nominal derivational elements coming with no category change which realize the transition pattern demonstrated in (9a.1) with an "intransitive" input (where 'intransitive' in the nominal category is to mean that a noun's ASV contains no possessor): ${ }^{4}$

(13) (a) Ez itt (egy) kalap.

this here (a) hat

'This here is a hat.'

(b) Ez itt a kalapja az én feledékeny

this here the hat-poss3sg the I absent-minded

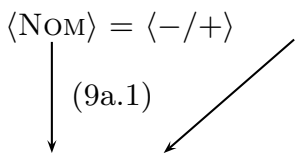

Péter barátomnak.

Peter friend-poss1sg-dat

'This is the hat of my absent-minded friend Peter.'

\footnotetext{
4 The other nominal derivative suffix -ÓjA (Laczkó 2000b), discussed in section 4 , obviously contains - $((j) A)$ (accompanied by the suffix of present participles), which we claim to be another argument in favor of classifying this (latter) suffix as a derivational element.
} 
(a) Gyakran darálnak a munkások ebben often grind-3pl the worker-pl this-ine a mühelyben.

the workshop-ine

'The workers often grind in this workshop.'

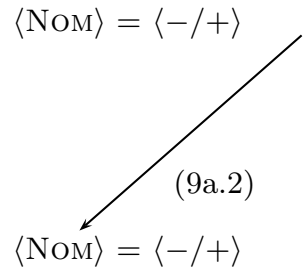

(b) Ez itt a daráló.

this here the grind-presprt

'This is the grinding workshop.'

In (14) above I have illustrated the derivational suffix - $O$ proposed by Laczkó (2000b) as a morpheme forming names of places following transition pattern (9a.2) (which is a transition with an intransitive input). An analogous example in the area of $\mathrm{V} \rightarrow \mathrm{V}$ derivations is épülnek a házak a hegyoldalon [build-3pl the house-pl the hill-side-sup] 'houses are built on the hill-side' $\rightarrow$ beépül a hegyoldal [into-build-past-3sg the hill-side] cca. 'the hill-side has been covered by new buildings' - which is an analogy that we judge to corroborate the hypothesis on the suffix - $O$ because of the similarity in respect of meaning.

Let us turn to the other subtype of argument-structure expanding derivations, in the course of which the chain of influence enriches at its negative edge. Let causative/factitive derivation be the first ASV transition to be commented on. As was shown by $(8 \mathrm{~b})$ in section $\mathbf{2}$, when the input is transitive, there is a replacement in the position of subject with object position remaining unaffected. In the (degenerate) case of an intransitive input, it is (9b.1) that can be called the productive transition pattern, in which the new subject "pushes" the input subject into the object position. As for the other intransitive transition pattern, shown in (9b.2), a few examples can be mentioned, which we judge to be relics in the synchronic state of language. In this latter subtype the output ASV is also intransitive (e.g., Hol/Kivel varratsz/lektoráltatsz mostanában? [where/who-inst sew-cause-2sg/revise-cause-2sg nowadays?] 'who is your new tailor/literary adviser?').

In connection with causative derivation it is worth discussing the distinction of the "phonetic reality" of particular derivational morphemes from the abstract level of ASV transition belonging to them. As for the former aspect, only - $(t) A t$ is claimed to be productive in Hungarian (Komlósy 2000) (e.g., dolgoztat [work-cause] 'make sy work', ásat [dig-cause] 'make sy dig'; -Aszt, for instance, is not productive (but see fagyaszt [freeze-Aszt] 'make sth frozen'). Word form *fagy(t)at, how- 
ever, does not exist in Hungarian. Its derivation is blocked, which can be attributed to the following mechanism: there is a transition fagy $\rightarrow$ fagyaszt in Hungarian which can be regarded as a relic that has survived in the synchronic state of the language, and this relic makes it redundant, and hence forbidden, to apply the productive procedure of derivation. A uniform picture of abstract transition patterns and phonetic variants can be worked out by understanding their relation as follows: the primary factor is the patterns of ASV transitions belonging to certain cells of the chart in the Appendix and associated with a predictable change of meaning, and it should be studied then what kind of phonetic form realizes certain types of transition depending on particular types of inputs. The picture may be fairly intricate in certain areas: in the area of Hungarian causative/factitive derivation, for instance, one productive suffixation works (-(t)At), which "keeps away", on the one hand, from transitions which are surviving relics (e.g., fö $(l) \rightarrow$ fö $z$ 'be on the boil' $\rightarrow$ 'cook', süllyed $\rightarrow$ süllyeszt 'sink intr $\rightarrow$ 'cause to sink'), and, on the other hand, from input-output pairs produced by other derivations (e.g., sárgul $\rightarrow$ sárgít, but *sárgultat 'become/make yellow', sötétedik $\rightarrow$ sötétit $/{ }^{*}$ sötéted( $\left.\boldsymbol{t}\right)$ et 'become/make dark'). The possibility of distinguishing these two levels is an advantageous feature of Model Tau. Transition patterns can be defined without referring to morphemes of derivation: they are elements of UG, which are expressed in a given language by means of diverse morphological tools.

Now let us scrutinize the derivational suffix -it, mentioned above. Its input case frame is necessarily intransitive because of the adjectival category, but the verbal category in the output already makes a transitive frame possible, which is due to pattern (9b.1). It is worth making a comparison between the productive -it and the improductive - $V l l$, which follows also transition pattern (9b.1). The essence of their difference can be elucidated by referring to thematic roles (but should be captured and calculated in Model Tau in another way): - it enriches the chain of influence with an Agent while - Vll with an Experiencer (drágít [expensive-it] 'make sth (more) expensive', versus drágáll [expensive-áll] 'consider sth to be expensive').

Examples (15)-(17) below serve as an illustration of relevant cases of noun formation. The corresponding transition patterns have also been given below. In (15) and (17) the argument obtaining the subject position - independently of the verbal, adjectival or nominal category of the input word - will be the Davidsonian or eventual argument of the input 
situation (e.g., Parsons 1995): something (the dangerous or surprising situation) is predicated of that it is nothing else but the activity of a lion's stroking or the fact that Mary is beautiful or a teacher. ${ }^{5}$ Type (15) has a transitive input, and in the subject position the Agent of the input will be replaced in the output ASV with what serves as the eventual argument in the input. Transition type (17) is degenerate as its input is intransitive; the transition can be described by (9b.1): the input subject will accept a possessor's function in order to be able to give the subject status to the eventual argument. The type demonstrated in (16) below (e.g., a kutya harapása [the dog bite-nominal-poss3sg] 'the bite of the dog', which is a result, and not an activity/state (see above)) is characterized by strictly restricted productivity, so I mention it only because of the famous ambiguity shown in (15)/(16). The transition in (16) can be captured essentially in the same way as those demonstrated in (17), with intransitive inputs (a kutya harap 'the dog bites').

(15) (a) Mari simogatja az oroszlánt.

Mary stroke-3sg the lion-acc

'Mary is stroking the lion.'

(b) Ami igazán veszélyes, az az oroszlánnak ${ }_{\mathrm{PAT}_{\mathrm{AT}}}$

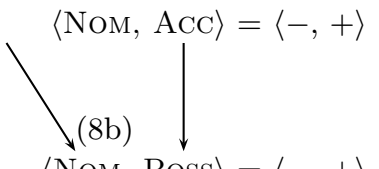
what really dangerous that the lion-dat

$\langle$ Nom, Poss $\rangle=\langle-,+\rangle$ a simogatása.

the stroke-nominal-poss3sg

'What is really dangerous is the stroking of the lion.'

(16) (a) ? Az oroszlán ${ }_{A G}$ ritkán simogat (inkább üt the lion rarely stroke (rather beat és karmol). and scratch) 'A lion rarely strokes, it rather beats and scratches.' $\backslash(9 \mathrm{~b} .1)$

(b) Amit itt láthatsz a karomon $\langle$ Nom, Poss $\rangle=\langle-,+\rangle$ what-acc here see-mod-2sg the arm-poss-1sg-sup az az oroszlánnak $\mathrm{AG}_{\mathrm{A}}$ a simogatása. that the lion-dat the stroke-nominal-poss3sg

'What you can see here on my arm is the lion's stroking.'

${ }^{5}$ Sentence (15a), for instance, is about three participants: the two "normal" arguments of the verbal predicator, Mary and a lion, and the fact that Mary is stroking the lion, which can be regarded as an additional, or rather, "the 0-th," argument. An independent piece of evidence in defence of this approach is the 
(17) (a) Mari szép / tanár.

Mary beautiful / teacher

'Mary is beatiful / a teacher.'

(b) Ami igazán meglepett, az Mari what really surprise-past-3sg that Mary

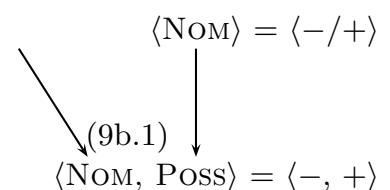

szépsége

/ tanársága.

beautiful-nominal-poss3sg / teacher-nominal-poss3sg

'What has really surprised me is the fact that Mary is beautiful/a teacher.'

(18) (a) Ez itt Pécs.

this here Pécs

'This here is Pécs.'

(b) Mari pécsi.

Mary Pécs-adj

'Mary is from Pécs.'

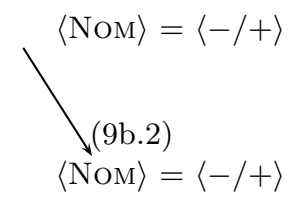

Finally a derivational suffix productively turning a certain type of nouns into adjectives should be mentioned, whose phonetic form is $-i$. As is illustrated by (18) above, now we should have recourse to the pattern of transition (9b.2), pertaining to intransitive inputs, which replaces a single central subject with another one.

\section{Kinds of derivation reducing argument structure}

This section is devoted to commenting on the last two parts of the systematizing chart in the Appendix, which contain ASV transitions essentially deleting one of the central arguments, at least from the central zone.

A transition like this can also be understood as the advancement of a central argument by assigning both central poles to it. As was pointed out in connection with (8) in section 2, advancement and degradation mutually trigger each other; a derivational transition, hence, can be attributed to one of these two operations, which can be called the decisive factor of the given transition, whilst qualifying the other operation as an additional element. It will be pointed out that the decisive factor can be

observation that these three participants can be referred to by (different sorts of) pronouns: e.g., Mary $y_{1}$ is stroking the lion $_{2}$ though she $e_{1}$ can see that it $t_{2}$ does not like that $t_{0}$. Mary $_{1}$, who $o_{1}$ is my brother's daughter, is stroking a lion ${ }_{2}$, which ${ }_{2}$ arrived at the zoo yesterday, which $_{0}$ requires serious braveness. 
decided on unambiguously if a derivation operates on intransitive inputs as well. In the chart the cell of each transition type is divided into two parts horizontally, and I show my hypothesis on the decisive factor of the given transition (advancement/degradation). I will note where the decision is obvious.

Let us start the detailed discussion with derivations deleting a positive central argument. In the simplest case an object is deleted, which can be called intransitivization and is realized in the form of conversion (in Hungarian), with limited productivity (Péter eszik/*helyez 'Peter eats/ *places'). The change in meaning can be approximated by the following formula: $\operatorname{ESZIK}_{\text {intr }}(x)=\exists y \cdot \operatorname{ESZIK}_{\mathrm{tr}}(x, y)$. In this logical formula, argument $\mathrm{y}$ is existentially bound, so syntax can provide for it no argument slot that could be freely occupied any more. The reason of this kind of semantic modification may lie in various factors: we cannot, or do not intend to, specify the kind of food (in the given case), or we intend to raise the hearer's attention to the Agent's impact upon himself/herself, i.e., (s)he is busy with eating or (s)he makes himself/herself strong or fat.

A syntactic argument - as a slot that can be filled in freely - can be expired also by identifying two arguments: for example, FÉsüL $\mathrm{L}_{\text {refl }}(x)$ $=$ FÉSÜL $\mathrm{L}_{\mathrm{tr}}(x, x)$ ('comb'/'comb oneself'). This kind of transition can be called reflexivization and is realized in Hungarian by a family of similar suffices (e.g., fésülködik, mosakodik, borotválkozik 'comb/wash/shave oneself'). Reflexivization makes it explicit that the Agent exerts some kind of influence upon himself/herself.

The object argument slot that can be filled in freely can also be ceased by incorporation. This transition via conversion can be characterized as follows: the object which typically appears in a non-determined form moves to the place immediately preceding the verb stem (while the sentence remains neutral) and forms a word-size intonational unit with it (with a single stress on the first syllable - in accordance with Hungarian phonology) (Komlósy 1992). The following formula is an illustration of the change in meaning: $\operatorname{SZEREL}_{\text {inc:Autó }}(x)=y$.[ $\left.\operatorname{SZEREL}_{\mathrm{tr}}(x, y) \& \operatorname{AUTÓ}(y)\right]$ ('repair' $\rightarrow$ 'car-acc+repair', see (19a-b) below). As is shown in (19b) below, what can be incorporated can be characterized as an object which is typical relative to the event, i.e., with which the given event can be regarded as "institutionalized" in a generalized sense (Komlósy ibid.). In $(19 a-b)$ the identity of the three types of transitions can be observed; what is different is the change in meaning, see the formulas in (19c.1-3) below: 
(19) (a) Péter eszik egy zsemlét / megfésüli magát / $\langle$ Nom, ACC $\rangle=\langle-,+\rangle$ Peter eat-3sg a roll-acc / perf-comb-3sg self-acc / szereli az autót. repair-3sg the car-acc 'Peter eats a roll/combs himself/repairs the car.'

(b) Péter eszik / fésülködik / autót /

Peter eat-3sg / perf-comb-refl-3sg / car-acc /

??? Fordot szerel. Ford-acc repair-3sg

'Peter eats/combs himself/repairs cars/Fords.'

(c) 1. $\mathrm{V}_{\mathrm{intr}}(x)=\exists y \cdot \mathrm{V}_{\mathrm{tr}}(x, y)$

2. $\mathrm{V}_{\text {refl }}(x)=\mathrm{V}_{\operatorname{tr}}(x, x)$

3. $\mathrm{V}_{\text {inc: } \mathrm{N}}(x)=\exists y \cdot\left[\mathrm{V}_{\operatorname{tr}}(x, y) \& \mathrm{~N}(y)\right]$

4. $\mathrm{V}_{\text {inc: } \mathrm{N}}()=\exists y \cdot\left[\mathrm{V}_{\operatorname{intr}}(y) \& \mathrm{~N}(y)\right]$

Is it possible in the case of the three sorts of derivations discussed above that the input is degenerate, i.e., intransitive? The answer is positive in the case of incorporation (and only in this case), as is witnessed by the example in (20) below: it has been observed that a Patient can be incorporated without the presence of an Agent in the argument structure whereas a lonely Agent cannot be incorporated. See the formula in (19c.4) above: the central zone of the output ASV in this degenerate case is empty. This circumstance also reveals that the decisive factor of incorporation is the degradation of the argument bearing the positive central role (and not the Agent's advancement). Thus positive central arguments will undergo this operation; and what (20b) shows is that the same can also be claimed by referring to the absolute character: independently of the input number of arguments, essentially Patients are pertained to (providing an example of Perlmutter's (1978) Unaccusative Hyposthesis).

This observation can be captured in Model Tau as follows: if the decisive factor of a transition in the case of which also an intransitive input is permitted is the operation (argument degradation/advancement) pertaining to the positive central argument, then, out of the arguments ordered in the chain of influence, there is an argument in the primitive core with the following property: the given derivation can be applied to the arguments in the chain in the positive direction, but not in the negative direction, relative to this distinguished argument. A strong agent, thus, cannot be incorporated (*régész ásat itt 'archeologist digcause here'), whereas in the case of a strong patient incorporation is 
theoretically permitted and its realization will depend on the pragmatic criterion of institutionalization, mentioned above (gödröt/sírt/aranyat ás 'hole-acc/grave-acc/gold-acc dig').

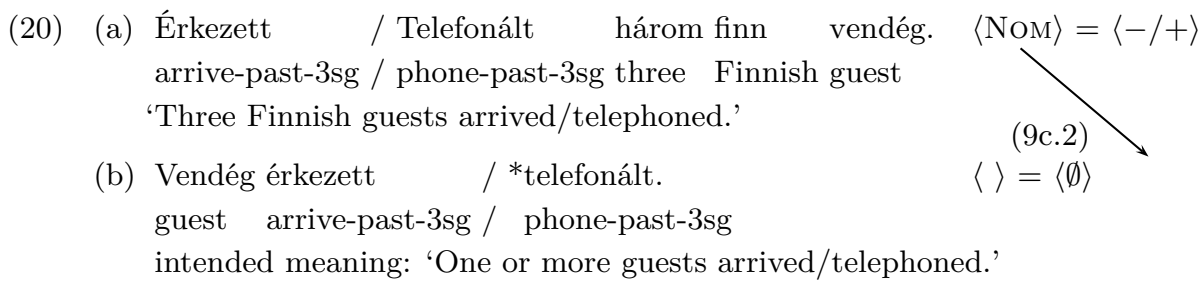

Let us return to cases of object degradation with a transitive input in favor of the versions of suffix - $O$ forming adjectives (and not present participles), carefully classified by Laczkó (2000a). Combining incorporation with adjective formation can result in the type of the example autószerelö (brigád) ['car-repair-Ó (team)'] 'team repairing cars' (which can also be regarded as the first step towards the noun autószerelo" ['car-repair-O'] 'car-mechanic', whose formation requires a second step discussed earlier, viz. a conversion retaining argument structure). In the type of adjective formation exemplified by a szeretö ${ }_{\mathrm{A}}$ fiad ['the love- $O$ son-poss2sg'] 'your son who loves you', the object cannot be chosen freely (cf. a Marit szeretö $_{\mathrm{V} \rightarrow \mathrm{A}}$ fiad ['the Mary-acc love- $O$ son-poss2sg'] 'your son who loves Mary'), so it has been deleted as a syntactic argument.

In (21)-(22) below analyses concerning noun formation are demonstrated. (21a) is intended to show (by means of a fictive verb stem) that $-O ́$ as a suffix forming nouns is productive in two versions, with output words referring to actors/instruments (Laczkó 2000b). Transition pattern (8c) accounts for both versions, which operate on different inputs, obviously. 
(21) (a) Az a munkás / gép ott álló nap that the worker / machine there whole day strimpfeli a biszcájgokat. strimpf-3sg the bißzeug-pl-acc 'That worker/machine there strimpfs the bißzeugs all the day.'

(b) Ö az új strimpfelö. / $\mathrm{Az}$ a gép egy he the new strimpf-Ó / that the machine a új német strimpfelö. new German strimpf-ó

'He is the new strimpfer. / That machine is a new German strimpfer.'

(22) (a) Ady új verse /

Ady new poem-poss3sg /

az autó örökös szerelése

the car unending repairing-poss3sg

'Ady's new poem' / 'the unending repairing of the car'

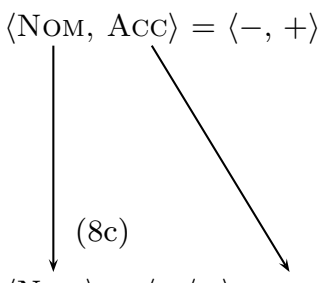

$\langle\mathrm{NOM}\rangle=\langle-/+\rangle$

(b) Ady-vers / autószerelés

$\langle\mathrm{NOM}\rangle=\langle-/+\rangle$

Ady-poem / car-repairing

'poem of Ady's' / 'repairing of cars'

The type of noun formation retaining category, demonstrated in (22) above, can also be traced back to transition pattern (8c), as the input word category defines the $\langle$ Nom, Poss $\rangle$ input case frame; what is yielded, then, as an output is a complex word including the original possessor incorporated. Note that the central frame, which is already rid of possessors, can be enriched with a possessor again in the way discussed in the previous section: Péter(-nek a) kedvenc Ady-verse 'Peter(-dat the) favorite Ady-poem-poss3sg' Péter(-nek az) örökös autószerelése 'Peter(-dat the) unending car-repairing-poss3sg'; while two possessors cannot remain in the central frame (despite the semantic possibility mentioned above), which is a correct prediction.

The last major section of the systematizing chart demonstrates transitions in the course of which the input subject is deleted (from the central zone), resulting in the input object advancing into a subject bearing a double central role (8d). In English, passivization can be characterized in this way (Alberti 1996, 1998a), whose crucial function in the system of this language is associating the Patient with a topic pragmatic role (closely related to the subject position in English); the cost, as a result 
of constraint (2a), is that the Agent should be deleted from the central frame as it is not permitted to appear as an object in the same ASV.

In Hungarian, passivization as a sort of verb formation is archaic, and, hence, cannot be characterized as productive (e.g., riporter kerestetik ['reporter seek-pass'] 'reporters are looked for', ilyen lehetöség ritkán adatik az embernek ['shuch chance rarely give-pass the man-dat'] 'a chance like this is rarely given to you'), and the formation of mediális (cca. 'middle') forms comes with a special additional meaning (e.g., magától megoldódott ['self-abl solve-mid-past'] 'solved of its own accord'); but participial and nominal outputs can be formed in many ways according to transition pattern (8d), as is shown by the densely covered lower part of the chart. (23) shows the straightforward cases:
(a) Péter megoldotta
a problémát.
Peter perf-solve-past-3sg the problem-acc 'Peter solved the problem.'

(b) A probléma megoldódott /

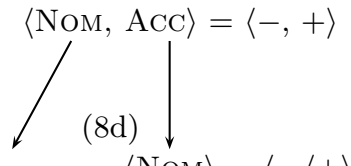

$\langle\mathrm{NOM}\rangle=\langle-/+\rangle$ the problem perf-solve-mid-past-3sg /

${ }^{\dagger}$ megoldatott / meg van oldva. perf-solve-mid-past-3sg / perf is solve-adv / megoldott / megoldandó / megoldható / perf-solve-pastprt / perf-solve-futprt / perf-solve- $h A t$ / megoldhatatlan / megoldatlan probléma perf-solve- $h A t A t l A n$ / perf-solve-AtlAn problem

'The problem was solved / was solved by sy / is solved.' / 'a problem which [has been solved] / [is to be solved] / [can be solved] / [cannot be solved] / [is not solved]'

Further comments are due on the sorts of derivation accepting even intransitive inputs: e.g., those forming adverbial participles ( $k i$ van apadva ['out is dry-adv'] 'is exhausted'), and past participles (kiapadt ['out-drypastprt'] 'exhausted'); -hAtAtlAn forms appear in numerous relics (kiapadhatatlan ['out-dry-hAtAtlAn'] 'inexhaustible') but this sort of derivation is not productive (cf. *kifáradhatatlan ['out-tire-hAtAtlAn'] 'untiring'). The decisive factor of the sorts of derivation, thus, is obviously the advancement of Patient (the argument with the positive central role), and not the degradation of Agent (Alberti 1996, 1998a), as the single argument will not undergo deletion; further, just intransitive ASVs consisting of a Patient will undergo these derivations, serving as an argument in 
favor of the law concerning transitions with a patient-like decisive factor, discussed above example (20).

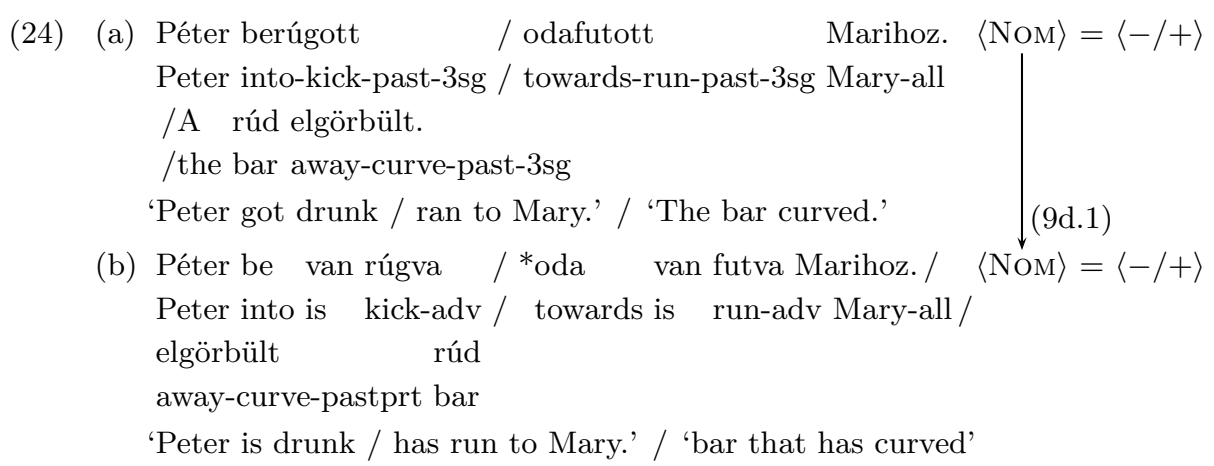

One might think that the Patient in an intransitive case frame cannot be advanced, as it already bears a double central role in the input ASV. This is true, but the functioning of advancing/degrading operations will be disturbed by no formal factors; in the degenerate situation they function as an identical mapping, with a benefit typical of the given category change (see Alberti-Ohnmacht 2005, and also Alberti 1996, 1998a).

There is a theoretical alternative: intransitive passivization might follow transition pattern (9d.2). The German Zustandpassiv, for instance, works in this way: e.g., Hier ist bis $23 \mathrm{Uhr}$ getanzt ['hier is until 23 o'clock perf-dance-pastprt'] 'one is allowed to dance here until 23.00'. As is pointed out by Tóth (2000), there is a narrow but clear-cut area (household verbs) within which adverbial participles can be formed also in Hungarian in this way (by deleting the single argument as a decisive factor of transition where this single argument should be agent-like):
(a) Mari kitakarított
/ beágyazott
a hatosban.
Mary out-clean-past-3sg / into-bed-past-3sg in six-ine 'Mary did room 6/turned down beds in room 6.'
(b) A hatosban ki van takarítva / be van ágyazva. the six-ine out is clean-adv / into is bed-adv 'Someone did room 6 / turned down beds in room 6.'

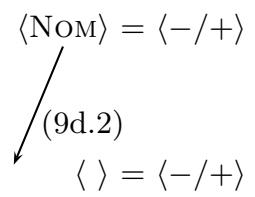

Let us return to the regular transition pattern provided in (8d). We can use this pattern to capture three types of derivation relying on properties of the central case frame attributed to nouns; see (26)-(28) below. The analysis shown in (26) provides a formal rule describing derivations with 
a nominal central frame as the starting point, i.e., essentially a possessive construction. Who is gondos ['care- $\left.(V) s^{\prime}\right]$ 'careful', for instance, takes care of the things (s)he is responsible for: the analysis in (26) below relies on this connection. An interesting question arises here: the ambiguity between gondtalan/gondatlan 'carefree'/'careless' (in which the same stem is furnished with two variants of the privative suffix -tAlAn/(A)tlAn), which can be explained as follows: gond 'care' can be understood as both a positive concept ('attention') and a negative one ('problem'), and this alternative in addition to the alternative forms of the privative suffix has made it possible to develop two different adjectival meanings in the course of the evolution of Hungarian. The transition pattern itself, after that, can be assumed to be the same. The derivational suffix $-(j) \dot{U}$ is special: while deleting the input subject (or rather, embedding it in the phonetic form of the predicator itself), it also has an additional effect outside the central zone, viz., it produces a predicative argument of category adjective (which corresponds to a qualifier in the input, which is a free adjunct) (Laczkó 2000c). This specialty, however, does not disturb our claims concerning changes in the central case frame.

(26) (a) Ez Marinak a gondja / (hosszú) haja. $\langle$ Nom, Poss $\rangle=\langle-,+\rangle$ this Mary-dat the care-poss3sg / (long) hair-poss3sg 'This is Mary's problem/(long) hair.'

(b) Mari gondos / gondtalan / gondatlan /

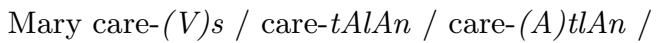

hosszú hajú.

long hair- $(j) U$

'Mary is careful / careless / care-free / long-haired.'

\footnotetext{
(a) Péter felrakta az árut.

Peter up-load-past-3sg the commodity-acc 'Peter loaded the commodity (onto sth).'

(b) Ez az áru viszonylag kellemes rakomány. this the commodity fairly pleasant load 'This commodity is a fairly pleasant load.'
}

The analysis above in (27) provides the transition pattern belonging to suffix - $(V) m A ́ n y$, which is very frequent but does not qualify as a morpheme of a productive derivation forming nouns (Kiefer-Ladányi 2000b). This is the transition pattern shown in (8d); and we should have recourse to its degenerate variant (9d.1) in favor of such examples with an intran- 
sitive input (consisting of a Patient!) as fejlemény ('develop/-ments'), eredmény ('grow out' $\rightarrow$ 'outgrowth'), esemény ('occur/-rence').

Finally let us consider the analysis requiring the most imagination. The derivational suffix $-l /-z$ forms verbs from nouns, so our starting point should be a possessive construction: this Peter-dat the hoe-poss3sg / rake-poss3sg /
(a) Ez Péternek a kapája / gereblyéje /
(b) Péter kapál / gereblyéz /
Peter hoe-3sg / rake-3sg /

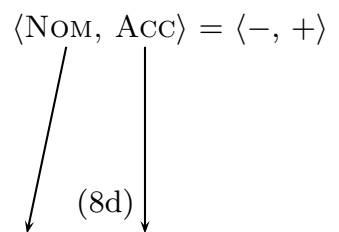
$\langle\mathrm{NOM}\rangle=\langle-/+\rangle$ gitározik / csajozik. play-the-guitar-3sg / go-out-with-a-girl-3sg 'Peter is hoeing/raking/playing the guitar/going out with a girl.'

Is it possible to base this formal analysis upon any kind of connection between an activity and possession (interpreted appropriately)? I think so; and the key to a solution like this lies in finding the proper interpretation of the construction $X$ 's $Y$ from the numerous interpretations. This input interpretation is as follows: $X$-nél van $Y$ (' $\mathrm{X}$-ade is $\mathrm{Y}$ ') 'there is a $\mathrm{Y}$ with $\mathrm{X}$ ', and then the output meaning can be formulated in this way: $X$ is doing something with $Y$ that is with him/her, which is an activity straightforwardly resulting from the inherent nature of $Y$. What one can do with a hoe or a guitar if properly used, for instance, is hoeing or playing the guitar.

\section{Summary}

Having reviewed all sorts of derivation characterized as productive in the volume on morphology of Strukturális magyar nyelvtan (Kiefer 2000), I claim that the a priori hypothesis has been corroborated: the original version of Model Tau (Alberti 1997), dealing only with verbal derivation coming with no category change, can be extended to the entire spectrum of derivations (typically coming with category change); moreover, it can be extended in the most straightforward way possible, according to which the single novel factor to be allowed for is the central case frame peculiar to particular word categories. 
I claim that if the predicator is a noun, what corresponds to the case frame $\langle\mathrm{NOM}, \mathrm{ACC}\rangle$ in the sphere of verbs, is the case frame $\langle\mathrm{NOM}$, Poss $\rangle$. This mapping is immediately observable in the case of $-O j A$, a suffix forming nouns in an argument-structure retaining way (Laczkó 2000b); see (10) in section 3. As for the totally productive suffix $-A ́ s$, forming nouns with an output meaning referring to facts/activities, it is less easy to capture its impact concerning the modification of case frame (15), but the pattern of transition corresponds to nothing else but the causative derivation (8b) in the sphere of $\mathrm{V} \rightarrow \mathrm{V}$ formation, which is also prominently productive. Now, instead of entering into further details, I would like to highlight the essence of Model Tau's theory on derivation: (8) shows the five patterns of case-frame transitions which can be calculated as theoretical possibilities in the case of a transitive input (independently of the pair of word categories concerned), and then (9) is intended to review the degenerate cases, i.e., transitions with an intransitive input ASV. As is demonstrated in the chart in the Appendix, what is predicted theoretically does manifest itself in the system of derivations of the Hungarian language; in this way we could work out a system revealing several hidden connections in an intricate area of grammatical description, which is a good way of verifying the explanatory adequacy of the theoretical framework.

As for further research in the area, beyond the "quantitative" problem of studying the derivational system of other languages, we would like to extend the theory to the area of aspect and event(uality) structure (Alberti-Ohnmacht 2005): we would like to base the calculation of eventuality structures of predicators upon the semantic properties of derivational operations producing these predicators step by step.

\section{References}

Alberti, Gábor 1988a. Tau modell (a természetes nyelv egy függvényszerkezetes modellje) [Model Tau: A model of natural language based on functions] (Mühelymunkák 4). MTA Nyelvtudományi Intézete, Budapest. 3-39.

Alberti, Gábor 1988b. Tau modell (a természetes nyelv egy sztochasztikus modellje) [Model Tau: A stochastic model of natural language]. Diploma work. Eötvös Loránd University (ELTE), Budapest.

Alberti, Gábor 1992-1993. Hatáslánc [Chains of influence]. In: Nyelvtudományi Közlemények 93 : 137-59.

Acta Linguistica Hungarica 53, 2006 
Alberti, Gábor 1994. Model Tau: A formal theory of thematic roles. In: Zoltán Bánréti (ed.): Papers in the theory of grammar, 184-235. Research Institute for Linguistics of the Hungarian Academy of Sciences, Budapest.

Alberti, Gábor 1995. Role assignment in Hungarian possessive constructions. In: István Kenesei (ed.): Approaches to Hungarian 5 (Levels and structures), 13-28. JATEPress, Szeged.

Alberti, Gábor 1996. Passzivizálási művelet a magyarban [Passivization in Hungarian]. In: Néprajz és Nyelvtudomány 2:7-46.

Alberti, Gábor 1997. Argument selection. Peter Lang, Frankfurt am Main.

Alberti, Gábor 1998a. On passivization in Hungarian. In: Casper de Groot-István Kenesei (eds): Approaches to Hungarian 6 (Papers from the Amsterdam conference), 103-22. JATEPress, Szeged.

Alberti, Gábor 1998b. Struktúrák a vonzatszerkezetben [Structures in argument structure]. In: László Büky - Márta Maleczki (eds): A mai magyar nyelv leírásának újabb módszerei III [Recent methods in the description of contemporary Hungarian 3], 185-221. JATEPress, Szeged.

Alberti, Gábor 2000. Jelentésleírás - „életfogytiglani” DRS ben [Describing meanings - in "lifelong" DRSs]. In: Tamás Gecső (ed.): Lexikális jelentés - aktuális jelentés, 12-25. Tinta Kiadó, Budapest.

Alberti, Gábor - Magdolna Ohnmacht 2005. Aspect and eventuality structure in Hungarian. Paper presented at the Seventh International Conference on the Structure of Hungarian, Veszprém, 29-31 May 2005.

Bene, Annamária 2005. Az igék bennható-mediális-tranzitív felosztásának alkalmazhatósága magyar szintaktikai és morfológiai sajátosságok magyarázatában [Applicability of the classification of verbs into unergative, unaccusative and transitive groups to explaining Hungarian syntactic and morphological phenomena]. Doctoral dissertation, Eötvös Loránd University (ELTE), Budapest.

Bresnan, Joan-Jonni M. Kanerva 1989. Locative inversion in Chichewa: A case study of factorization in grammar. In: Linguistic Inquiry $20: 1-50$.

Dowty, David R. 1991. Thematic proto-roles and argument selection. In: Language $67: 547-619$.

Fillmore, Charles J. 1968. The case for case. In: Emmon Bach-Robert T. Harms (eds): Universals in linguistic theory, 1-88. Holt, Rinehart and Winston, New York.

Grimshaw, Jane 1990. Argument structure (Linguistic Inquiry Monograph 18). MIT Press, Cambridge MA.

Gruber, Jeff 1965. Studies in lexical relations. Doctoral dissertation, MIT, Cambridge MA. Published as Lexical Structures in Syntax and Semantics. North Holland, Amsterdam, 1976.

Jackendoff, Ray 1987. The status of thematic relations in linguistic theory. In: Linguistic Inquiry 18:369-411.

Kenesei, István 2000. Szavak, szófajok, toldalékok [Words, parts of speech, affixes]. In: Kiefer (2000, 75-136).

Kiefer, Ferenc (ed.) 2000. Strukturális magyar nyelvtan 3. Morfológia [A structural grammar of Hungarian, Vol. 3: Morphology]. Akadémiai Kiadó, Budapest.

Acta Linguistica Hungarica 53, 2006 
Kiefer, Ferenc - Mária Ladányi 2000a. A szóképzés [Word formation]. In: Kiefer (2000, 137-64).

Kiefer, Ferenc - Mária Ladányi 2000b. Morfoszintaktikailag semleges képzések [Morphosyntax-neutral derivation]. In: Kiefer (2000, 165-214).

Komlósy, András 1982. Deep structure cases reinterpreted. In: Ferenc Kiefer (ed.): Hungarian general linguistics, linguistic and literary studies in Eastern Europe 4, 351-85. John Benjamins, Amsterdam \& Philadelphia.

Komlósy, András 1992. Régensek és vonzatok [Valence and government]. In: Ferenc Kiefer (ed.): Strukturális magyar nyelvtan 1. Mondattan [A structural grammar of Hungarian, Vol. 1: Syntax], 299-527. Akadémiai Kiadó, Budapest.

Komlósy, András 2000. A müveltetés [Causativization]. In: Kiefer (2000, 215-92).

Laczkó, Tibor 2000a. A melléknévi és határozói igenévképzők [Forming adjectival and adverbial participles]. In: Kiefer (2000, 409-52).

Laczkó, Tibor 2000b. Az ige argumentumszerkezetét megőrző fönévképzés [Nominal derivation retaining the argument structure of the base verb]. In: Kiefer (2000, 293-407).

Laczkó, Tibor 2000c. Zárójelezési paradoxonok [Bracketing paradoxes]. In: Kiefer $(2000,619-52)$.

Parsons, Terence 1995. Thematic relations and arguments. In: Linguistic Inquiry 26 : 635-62.

Perlmutter, David 1978. The unaccusative hypothesis and multiattachment: Italian evidence. Paper presented to the Harvard Linguistics Circle, May 9, 1978.

Rappaport, Malka - Beth Levin 1988. What to do with theta-roles? (Syntax and Semantics 21: Thematic Relations). Academic Press, New York.

Szabolcsi, Anna 1992. A birtokos szerkezet és az egzisztenciális mondat [The possessive construction and the existential sentence]. Akadémiai Kiadó, Budapest.

Tenny, Carol L. 1994. Aspectual roles and the syntax-semantics interface. (Studies in Linguistics and Philosophy 52). Kluwer, Dordrecht.

Tóth, Ildikó 2000. Inflected infinitives in Hungarian. Doctoral dissertation, Tilburg University.

Williams, Edwin 1995. Theta theory. In: Gert Webelhuth (ed.): Government and binding theory and the minimalist program. Principles and parameters in syntactic theory, 99-124. Blackwell, Cambridge MA \& Oxford.

Zsilka, János 1966. A magyar mondatformák rendszere és az esetrendszer [The system of Hungarian sentence structures and cases] (Nyelvtudományi Értekezések 53). Akadémiai Kiadó, Budapest.

Zsilka, János 1982. De constructione (Történet és állapot egysége a nyelvben) [De constructione (The unity of diachrony and synchrony in language)]. Akadémiai Kiadó, Budapest.

Acta Linguistica Hungarica 53, 2006 


\section{Appendix}

The system of Hungarian (semi-) productive derivational suffixes on the basis of transition patterns of case frames (see comments in sections 3-5)

\begin{tabular}{|c|c|c|c|c|}
\hline & & $\langle\mathrm{NOM} / \mathrm{POSS} / \emptyset, \mathrm{ACC} / \emptyset\rangle$ & $\langle\mathrm{NOM} / \emptyset\rangle$ & $\langle\mathrm{NOM} / \emptyset, \mathrm{POSS}\rangle$ \\
\hline & থ & V / [Participle $]$ & $\mathrm{A} / \mathrm{Adv}$ & $\mathrm{N}$ \\
\hline \multirow[t]{3}{*}{$\begin{array}{llll}-\mathrm{N} & -\mathrm{C} & +\mathrm{C} & +\mathrm{N} \\
& \boldsymbol{\Downarrow} & \boldsymbol{\Downarrow} & \\
-\mathrm{N} & -\mathrm{C} & +\mathrm{C} & +\mathrm{N}\end{array}$} & $\mathrm{V}$ & 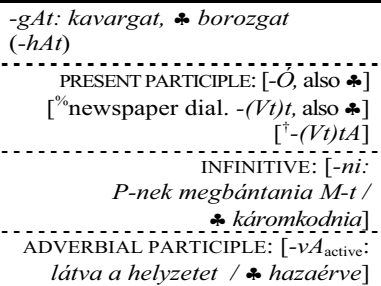 & (-ékeny/ékony) & $\begin{array}{l}\text {-OjA: Mari Péter(-nek } \\
\text { a) szeretöjel } \\
\text { elcsábitója }\end{array}$ \\
\hline & $\mathrm{A}$ & $\begin{array}{l}\text {-Vdik: sötétedik } \\
\text {-Ul: kizöldül } \\
\text {-(Vl)lik: sárgállik }\end{array}$ & $\begin{array}{l}-(A)_{s:} \text { zöldes } \\
\text {-AtlAn, -tAlAn: } \\
\text { bátortalan,szerénytelen } \\
- \text { Ann: részegen } \\
\text {-Ul: cudarul }\end{array}$ & $\begin{array}{l}\text { conversion: } \text { angol }_{N} \\
\text { (szeretó }_{N}, \\
\text { autószerelö }{ }_{N} \text { ) }\end{array}$ \\
\hline & $\mathrm{N}$ & $\begin{array}{l}\text {-(Vs)kodik: basáskodik, } \\
\text { katonáskodik }\end{array}$ & (conversion: király ${ }_{A}$ ) & $\begin{array}{l}-(V)(c s) k A \text { and other } \\
\text { diminutive der. suf. }\end{array}$ \\
\hline \multirow[t]{3}{*}{$\begin{array}{lll}-\mathrm{N} & -\mathrm{C}+\mathrm{C}+\mathbf{N} \\
& \mathbf{k} \\
& \mathbf{k} \\
-\mathrm{y} & -\mathrm{C} & +\mathrm{C}+\mathrm{N}\end{array}$} & $\mathrm{V}$ & $\begin{array}{l}\text { ken / fakaszt } \\
\text { * (be)épül, zsong / fakad } \\
\text { * megtelefonál } \\
\text { "pseudo-objects" }\end{array}$ & & *-ÓO$:$ daráló (place) \\
\hline & A & & & \\
\hline & $\mathrm{N}$ & & & \& possessive: $-(j) A$ ? \\
\hline \multirow{3}{*}{$\begin{array}{l}-\mathbf{N}-\mathrm{C}+\mathrm{C}+\mathrm{N} \\
\underset{(\mathbf{K})}{-\mathrm{N}}-\mathrm{C}+\mathrm{C}+\mathrm{N}\end{array}$} & $\mathrm{V}$ & $\begin{array}{l}\text { caus.: -(t)At: ásat } \\
\text { * dolgoztat vkit (vkivel/vhol) } \\
\text { (non-prod. elsüllyeszt) }\end{array}$ & & $\begin{array}{l}\text {-Ás: az o.PT } \\
\text { simogatása } \\
\text { *-Ás: az o.AG sim-a }\end{array}$ \\
\hline & $\mathrm{A}$ & $\begin{array}{l}\text {-it: drágít } \\
\text { (-Vll: drágáll) }\end{array}$ & & -sÁg: szépsége \\
\hline & $\bar{N}$ & & $-i$ :pécsi & $\begin{array}{l}\text {-sÁg: királysága, } \\
\text { tanársága }\end{array}$ \\
\hline \multirow{5}{*}{$\begin{array}{ccc}-\mathrm{N} & -\mathrm{C}+\mathrm{C}+\mathrm{N} \\
\mathbf{y} & \mathbf{y} \\
-\mathrm{N} & -\mathrm{C}+\mathrm{C}+\mathrm{N}\end{array}$} & $\mathrm{V}$ & $\begin{array}{l}\text { intransitivization: eszik, olvas } \\
\text { refl.: fésüllködik }\end{array}$ & -Ó: a szeretö fiad & $\begin{array}{l}\text {-Ó } \dot{O}_{1 / 2}: \text { daráló (worker } \\
\text { / instrument) }\end{array}$ \\
\hline & & $\begin{array}{l}\text { (patient) incorp.: autót szerel, } \\
\text { * fiú születik/vendég érkezik }\end{array}$ & $\begin{array}{l}\text {-Ó: autószerelö } \\
\text { (brigád) }\end{array}$ & \\
\hline & A & & & \\
\hline & $\mathrm{N}$ & & & \\
\hline & & & & $\begin{array}{l}\text { possessor incorp.: } \\
\text { Ady-vers, } \\
\text { autószerelés }\end{array}$ \\
\hline \multirow{4}{*}{$\begin{array}{l}-\mathrm{N}-\mathrm{C}+\mathrm{C}+\mathrm{N} \\
-\mathrm{K} \\
\boldsymbol{K}^{\boldsymbol{K}}-\mathrm{C}+\mathrm{C}+\mathrm{N}\end{array}$} & $\mathrm{V}$ & 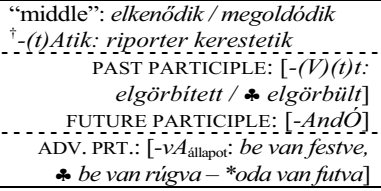 & $\begin{array}{l}\text {-hAtO: megoldható } \\
\text {-hAtAtlAn: } \\
\text { megoldhatatlan, } \\
(* \text { kiapadhatatlan - } \\
\text { *kimerülhetetlen } \\
\text { *elmehetetlen) } \\
\text {-AtlAn: megoldatlan }\end{array}$ & $\begin{array}{l}\text { (-mÁny: } \\
\text { rakomány, } \\
\text { * fejlemény) }\end{array}$ \\
\hline & & 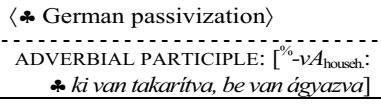 & & \\
\hline & A & & & \\
\hline & $\mathrm{N}$ & $\begin{array}{l}\text {-l: kapál } \\
\text {-z: gereblyéz }\end{array}$ & $\begin{array}{l}\text {-Vs: gond- } \\
\text {-(A)tlAn, -t(A)lAn } \\
\text {-(j)Ú: hosszú hajú }\end{array}$ & \\
\hline
\end{tabular}

Acta Linguistica Hungarica 53, 2006 